Yury Arzhanov

Porphyry, On Principles and Matter 


\section{Scientia Graeco-Arabica}

Herausgegeben von

Marwan Rashed

\section{Band 34}




\section{Yury Arzhanov}

\section{Porphyry, \\ On Principles and Matter}

A Syriac Version of a Lost Greek Text with an English

Translation, Introduction, and Glossaries

\section{DE GRUYTER}


ISBN 978-3-11-074577-1

e-ISBN (PDF) 978-3-11-074702-7

ISSN 1868-7172

Library of Congress Control Number: 2021940470

Bibliographic information published by the Deutsche Nationalbibliothek

The Deutsche Nationalbibliothek lists this publication in the Deutsche Nationalbibliografie; detailed bibliographic data are available on the Internet at http://dnb.dnb.de.

(C) 2021 Walter de Gruyter GmbH, Berlin/Boston

Printing and binding: $\mathrm{CPI}$ books $\mathrm{GmbH}$, Leck

Printed in Germany

www.degruyter.com 